\title{
RESERVE MOBILIZATION DURING IMBIBITION OF STORED Gliricidia sepium (Jacq.) Steud. (LEGUMINOSAE - PAPILIONOIDEAE) SEEDS ${ }^{1}$
}

\author{
RENATA CONDURU RIBEIRO REIS ${ }^{2}$, BÁRBARA FRANÇA DANTAS ${ }^{3}$; RENATO DELMONDEZ DE \\ CASTRO ${ }^{4}$; CIMILLE GABRIELLE CARDOSO ANTUNES ${ }^{2}$; FABRÍCIO FRANCISCO SANTOS DA SILVA ${ }^{3}$; \\ CLAUDINÉIA REGINA PELACANI²
}

\begin{abstract}
Gliricidia sepium is a drought-tolerant species, easily multiplied by seeds, and has been exploited by farmers as a source of forage in the semi-arid region of northeast Brazil. The objective of the present study was to evaluate the effect of seed storage on the mobilization of reserves during imbibition of "Gliricidia" seeds. Freshly-harvested seeds were packed in kraft paper bags and stored for three and six months in the laboratory under ambient conditions $\left(25^{\circ}\right.$ $\mathrm{C} \pm 3 \mathrm{~T}$ and $75 \% \pm 3 \mathrm{RH}$ ). Cotyledons were isolated from imbibed seeds and macerated for the extraction and quantification of total soluble sugars, reducing sugars, sucrose and starch, as well as of proteins, amino acids and for amylase activity. Storage under these conditions resulted in an increase in seed water content although germination remained at relatively high levels (86\%). Seed macromolecule levels showed significant variation with the storage period and imbibition and these variations were associated with a loss in seed viability due to inadequate storage conditions.
\end{abstract}

Index terms: macromolecules, longevity, viability, germination, water content.

\section{MOBILIZAÇÃO DE RESERVAS DURANTE A EMBEBIÇÃO DE SEMENTES DE Gliricidia sepium (Jacq.) Steud. (LEGUMINOSAE - PAPILIONOIDEAE) ARMAZENADAS}

\begin{abstract}
RESUMO - Gliricidia sepium é uma espécie que apresenta resistência à seca e facilidade em se propagar por sementes, sendo intensamente explorada como forrageira no semi-árido nordestino. O presente estudo foi desenvolvido para avaliar o efeito do armazenamento na mobilização de açúcares e proteínas e as possíveis modificações dessas macromoléculas de reserva durante a germinação de sementes de gliricidia. Sementes recém coletadas foram armazenadas por três e seis meses em sacos de papel kraft à temperatura ambiente $\left(25^{\circ} \mathrm{C} \pm 3 \mathrm{~T}\right.$ e $\left.75 \% \pm 3 \mathrm{UR}\right)$. Os cotilédones das sementes embebidas foram extraídos e macerados para a quantificação dos açúcares solúveis totais, açúcares redutores, sacarose, amido, proteínas, aminoácidos e atividade enzimática. $\mathrm{O}$ armazenamento em embalagem de papel kraft em temperatura ambiente propiciou o aumento no teor de água embora a capacidade germinativa fosse mantida em níveis altos (86\%). O armazenamento e o tempo de embebição influenciaram os níveis de macromoléculas nas sementes. A variação nos teores de macromoléculas esta associada com a perda da viabilidade das sementes proporcionada pela condição inadequada de armazenamento.
\end{abstract}

Termos para indexação: macromoléculas, longevidade, viabilidade, germinação, teor de água.

\footnotetext{
${ }^{1}$ Submitted on 14/12/2009. Accepted for publication on 04/03/11.

${ }^{2}$ Laboratório de Germinação - LAGER, Unidade Experimental Horto Florestal - Departamento de Biologia - UEFS, Av. Transnordestina, s/n, Novo Horizonte, CEP: 44036-900-Feira de Santana, Bahia, Brazil -

*Corresponding Author: rconduru@gmail.com
}

${ }^{3}$ Laboratório de Análise de Sementes - LASESA, Embrapa Semi-Árido, BR 428, Km 152, Zona Rural, C.P. 23, CEP: 56320-970-Petrolina, Pernambuco, Brazil.

${ }^{4}$ Departamento de Biofunção - Instituto de Ciências da Saúde/UFBA, Av. Reitor Miguel Calman, s/n, Vale do Canela, CEP: 40110-902, Salvador, Bahia, Brazil. 


\section{INTRODUCTION}

Gliricidia (Gliricidia sepium (Jacq.) Steud.) (Leguminosae - Papilionoideae) is a native species from South and Central America and was introduced into the Brazilian northeast region during the 1980 's. It is commercially and economically important for the region due to its multiple characteristics, combining drought tolerance with a high nutritional value and is, therefore, an important alternative source of forage and used in green fences and pastures. The rigorous climatic conditions of the Brazilian semi-arid region occur mainly between May and October due to the lack of rain and strong, dry winds, contributing to a dry and arid landscape (Sampaio and Rodal, 2000; Teixeira, 2001). During this period, seeds may remain viable in the soil seed bank, e.g. orthodox seeds (Baskin and Baskin, 1998) and drought resistance is one of the most important characteristics for maintaining seed viability during droughts and for cultivating tree species in the region. In this context, gliricidia stands out since it multiplies easily by seed, has fast growth, a high regeneration capacity and is drought resistant (Drumond and Carvalho Filho, 1999). Although the plant vegetative characteristics adapted to semi-arid environmental conditions are well-known, there is still much to learn about seed adaptation mechanisms under such conditions and soil seed banks are one of the main survival strategies of wild plant species (Baskin and Baskin, 1998).

The maturation of orthodox seeds is characterized by an intense deposition of reserves, after which there is an exclusive process of rapid water reduction, which varies according to the species and the prevalent climatic conditions. This dehydration results in the seeds becoming metabolically quiescent, allowing seed survival until conditions are once again favorable for germination (Bewley and Black, 1985). During this period, seed storage conditions are extremely important for maintaining viability as long as possible, e.g. longevity, and water uptake and storage temperature are the most critical factors (Ward and Powell, 1983). Therefore, the potential for seed conservation, or longevity, depends directly on the initial seed (physiological) quality before storage.

Desiccation tolerance is a common feature of orthodox seeds, generally attained during maturation and allows them to be stored for different periods of time, i.e. for many years in some cases, without a significant loss in viability
(Maluf and Pisciottano-Ereio, 2005). Such tolerance has been associated with the capacity of an organism, i.e. a seed, to withstand extreme stress conditions of almost complete water loss during maturation and its rehydration during the germination process (Hoekstra et al., 2003).

After maturation, seeds are subjected to a series of degenerative physiological, physical and biochemical changes, which are associated with a reduction in vigor (Alizaga et al., 1990). The occurrence of some processes in seeds, such as the Amadori and Maillard reactions, can contribute to deterioration and a loss in seed viability. These reactions apparently lead to metal complexation and can, therefore, reduce protein digestibility, inhibit the action of digestive enzymes, destroy amino acids and ascorbic acid and intervene in mineral metabolism (Araújo, 1995). Once these reactions are triggered by an increase in the water content of quiescent seeds, the environmental conditions and the type of reserves supplied will significantly influence the maintenance of seed physiological quality.

The germination process starts with seed imbibition as a result of water uptake. This occurs due to a difference in osmotic potential between the dry seed and the moist environment or substratum. However, the seeds must reach an adequate level of hydration to allow reactivation of seed metabolic processes, such as reserve mobilization, so that the resulting metabolites can be used by the germinating embryo and for subsequent seedling growth (Bewley and Black, 1994). In addition to tissue re-hydration, which occurs during the first phases of seed imbibition, germination is characterized by the mobilization of accumulated seed reserves. These reserves are degraded and mobilized in order to promote embryo development. Starch is one of the many types of seed reserves and the principal reserve polymer in legume seeds, and it is metabolized by hydrolytic enzymes, often $\alpha$-amylase (Buckeridge et al., 2004). This enzyme hydrolyzes the $\alpha-1,4$ bonds of the starch molecule, producing various oligosaccharides (Bewley and Black, 1994).

Much is still unknown about the mechanisms for maintaining seed viability, longevity and conservation, and about the processes for reserve mobilization during the germination of native or adapted species from the northeast, semi-arid region of Brazil. Therefore, the present study made an ex situ evaluation of possible modifications in the composition of reserves as a result of storage of G. sepium seeds under laboratory conditions, as well as their subsequent mobilization 
during germination. This study aimed to analyze the possible effects of storage on initial seed physiological quality and search for comparative parameters that could be applied under the natural conditions in which gliricidia seeds are kept as viable in soil seed banks of the northeastern semi-arid. A further aim was to analyze if those parameters could contribute as evidences for outstanding rusticity and tolerance of this species to the adverse drought stress conditions that are common in this region of Brazil.

\section{MATERIAL AND METHODS}

\section{Seed origin and storage}

Mature seeds were collected in 2006 from Gliricidia sepium trees at the "Fazenda Morrinhos", Queimadas county, Bahia state (W 39 $49^{\circ} \mathrm{S} 11^{\circ} 12^{\prime}$ ), considered as a 'Private Reserve' under Brazilian law. Freshly collected seeds were processed and subsequently used for laboratory analysis or packed in kraft paper bags (permeable) and stored for three and six months under ambient conditions $\left(25^{\circ} \mathrm{C} \pm 3 \mathrm{~T}\right.$ and $\left.75 \% \pm 3\right)$ at the Germination Laboratory of the State University of Feira de Santana (Laboratório de Germinação, Unidade Experimental Horto Florestal UEFS, Feira de Santana, Bahia). The stored seeds were divided into two lots and stored for three and six months. These lots were evaluated for water content, germination tests and assays for seed reserve mobilization.

\section{Germination}

Germination tests were conducted on freshly collected seeds and also after each storage period, using four replicates of 25 seeds placed on two layers of germination paper (Germitest) in $90 \mathrm{~mm}$ Petri dishes, soaked with a volume of water equivalent to 2.5 times the weight of the substrate. The seeds were incubated in germinator chambers at $25^{\circ} \mathrm{C}$, with a photoperiod regime of $14 \mathrm{~h}$ for 10 consecutive days. Seeds were considered as germinated when their radicles had protruded at least 2 $\mathrm{mm}$, after which they were scored and discarded.

\section{Seed water content}

The seed water content was evaluated after each storage period by the oven method, drying the seeds at 105 ${ }^{\circ} \mathrm{C} \pm 3$ for $24 \mathrm{~h}$, as described by the "Regras para Análise de Sementes" (Brasil 1992), using four replications of 25 seeds for each packaging and the environmental conditions in which the seeds were stored.

\section{Extraction and analysis of macromolecules} (carbohydrates, proteins and amino acids)

Macromolecule extraction and analysis were performed at the Laboratory of Seed Analysis, at the Embrapa Semiarid Research Center, in Petrolina, Pernambuco state, Brazil. Four replicates of 25 seeds were assayed at each storage period. The seeds were incubated at $25{ }^{\circ} \mathrm{C}$ in germination chambers during four imbibition periods: 24, 48, 72 and $96 \mathrm{~h}$. The germinated seeds, with $2 \mathrm{~mm}$ radicle protrusion, were counted for each imbibitions period and the cotyledons collected and stored at $-20{ }^{\circ} \mathrm{C}$ until extraction.

Macromolecules were extracted from samples of $1 \mathrm{~g}$ of fresh cotyledons that had been homogenized in $5 \mathrm{~mL}$ of $80 \%$ ethanol and centrifuged at $10,000 \mathrm{~g}$ for $20 \mathrm{~min}$ at $5{ }^{\circ} \mathrm{C}$. This procedure was repeated four times and the supernatants collected from each constituted sample (Seiffert, 2003).

Soluble compounds were quantified spectrophotometrically in aliquots of the ethanolic extracts. Total soluble sugars (TSS) were quantified by the method of reactions with antrona (Morris, 1948; Yemm and Willis, 1954); reducing sugars (RS) by the method of oxidation with 3,5-dinitrosalicylic acid (DNS) (Miller, 1959); sucrose (SUC) by the antrona cold reaction, after addition of hot $\mathrm{KOH}$ (Passos, 1996); total proteins (TP) according to Bradford's (1976) method and amino acids (AA) according to Rosen's (1957) method.

The pellets obtained after each centrifugation were dried in incubator at $60{ }^{\circ} \mathrm{C}$ for approximately $18 \mathrm{~h}$ (overnight). The dried materials were macerated and $0.1 \mathrm{~g}$ samples placed in microtubes for posterior starch digestion (S) using perchloric acid (Allen et al., 1977). The sugars obtained from the starch digestion were quantified from the TSS concentration present in each sample (Morris, 1948; Yemm and Willis, 1954).

\section{Enzyme extraction and analysis of enzymatic activity}

Alpha-amylase and total amylase activity were evaluated in freshly collected seeds and in seeds stored for three and six months. Seed lots were divided into four subsamples for the four imbibition periods: zero (quiescent seeds), 48, 96 and $168 \mathrm{~h}$ germinating seeds. The seeds were incubated at $25{ }^{\circ} \mathrm{C}$ in germination chambers during these periods. The germinated seeds with $2 \mathrm{~mm}$ radicle protrusion were counted and the cotyledons were collected and stored at $-20{ }^{\circ} \mathrm{C}$ until enzyme extractions and assays were made.

Extraction and assay of the amylase enzymes were performed according to the methods described by 
Gugelmineti et al. (1995). The cotyledons (1 g) were macerated in 0.1 mol. $\mathrm{L}^{-1} \mathrm{pH} 7$ TRIS-HCl buffer containing 0.1 mol. $\mathrm{L}^{-1} \mathrm{NaCl}$ and $10 \mathrm{mmol} . \mathrm{L}^{-1} \mathrm{CaCl}_{2}$ using a mortar and pestle. The resulting homogenate was centrifuged at $12,000 \mathrm{~g}$ for 10 minutes at $4{ }^{\circ} \mathrm{C}$. All supernatants were collected and stored at $-20{ }^{\circ} \mathrm{C}$ until the enzyme assays were performed. Total amylase and $\alpha$-amylase activity were measured in a reaction system composed of a reaction buffer $\left(50\right.$ mmol. $\mathrm{L}^{-1}$ sodium acetate $\mathrm{pH} 5.2$ and $10 \mathrm{mmol} . \mathrm{L}^{-1} \mathrm{CaCl}_{2}$ ), with a substrate of soluble potato starch $(2.5 \%)$. The reaction system was divided into two parts, and the first portion was incubated at $35{ }^{\circ} \mathrm{C}$ for 15 minutes. To inactivate the other amylases (leaving only $\alpha$-amylase), the second portion of the crude extract was maintained at $70{ }^{\circ} \mathrm{C}$ for 15 minutes before starting enzyme analysis. At the end of the reaction periods, free reducing sugars were quantified by the dinitrosalicylic acid (DNS) method using a spectrophotometer $(540 \mathrm{~nm})$. Total amylase and $\alpha$-amylase activities were expressed in mmol of reducing sugar produced by the degradation of starch, per gram of fresh material per minute.

\section{Statistical analysis}

Germination and water content data were expressed as a percentage and the standard mean error was calculated. Macromolecule data were analyzed by a variance analysis using the Sisvar 4.3 software program (Ferreira, 2000).
The means were compared by Tukey's test at the 5\% probability level. For the adjustment of regression equations, the significative model was used, which showed the highest determination coefficient.

\section{RESULTS AND DISCUSSION}

The macromolecule contents in seed cotyledons were significantly affected by variations in storage time and imbibition, except for the starch and protein contents, which were not influenced by the imbibition time. In general, all macromolecule contents varied when analyzed in relation to the combined effects of storage and imbibition times (Table 1). Increasing storage time significantly altered enzyme activity but no significant differences were observed for total amylase and a-amylase during the period of seed imbibition, although there was a significant interaction between the two parameters (Table 1).

Recentlyharvested seeds showed ahighergermination percentage than stored seeds. A $14 \%$ decrease in total percentage seed germination was observed in seeds with a higher water content after six months storage. The seeds stored in paper bags under ambient conditions had a higher water content, varying from $6.4 \%$ at harvest to $13.5 \%$ after six months storage, associated with the relative humidity during storage (Figure 1).

TABLE 1. Values for the variance analysis of macromolecule contents in Gliricidia. sepium seeds during storage and imbibition. $\mathrm{G} \%=$ germination; $\mathrm{ST}=$ starch; $\mathrm{SUC}=$ sucrose; $\mathrm{TSS}=$ total soluble sugars; $\mathrm{RS}=$ reducing sugars; $\mathrm{TP}=$ total proteins; $\mathrm{AA}=$ amino acids; $\mathrm{AT}=$ total amylase $\boldsymbol{\alpha}$-A= $\alpha$-amylase.

\begin{tabular}{lccccccccc}
\hline \multicolumn{1}{c}{ Source of variation } & G\% & ST & SUC & TSS & RS & TP & AA & AT & $\alpha-A$ \\
\hline Storage & $141.24 *$ & $72.324 *$ & $331.40 *$ & $178.86 *$ & $106.25 *$ & $7.15 *$ & $33.64 *$ & $25.49 *$ & $3.994 *$ \\
Imbibition & $238.14 *$ & $1.424^{\mathrm{ns}}$ & $108.61 *$ & $81.99 *$ & $10.868 *$ & $1.755^{\mathrm{ns}}$ & $3.233 *$ & $0.592^{\mathrm{ns}}$ & $0.512^{\mathrm{ns}}$ \\
Storage*Imbibition & $12.481^{*}$ & $18.658^{*}$ & $15.264 *$ & $7.337 *$ & $3.680 *$ & $3.311 *$ & $5.950 *$ & $3.316^{*}$ & $6.483 *$ \\
CV \% & 14.87 & 25.34 & 21.02 & 14.96 & 18.18 & 18.71 & 11.30 & 9.68 & 14.10 \\
\hline
\end{tabular}

$\mathrm{ns}=$ not significant; * significant at $5 \%$ respectively by $\mathrm{F}$ test.

Permeable packaging which permits water vapor exchange between the seeds and the atmosphere is more suitable for use in dry environments and for short storage periods. Freitas et al. (1992) reported that seeds maintained in highly permeable packaging in humid environments deteriorate quickly. Cisneiros et al. (2003) observed that seeds of Psidium guineense stored in paper bags increased their water content even when stored in a freezer and their germination ability was sharply reduced over time.

Seed longevity is greatly influenced by storage conditions, mainly by environmental temperature and humidity, which can influence seed water content and metabolism. In seeds of Campomanesia phaea (Myrtaceae), seeds stored under ambient conditions and packed in paper bags lost all their viability after 240 days of storage but seed conservation improved when seeds 
were stored in plastic bags under controlled conditions in cold chambers (Maluf and Pisciottano-Ereio, 2005). The beneficial effect of this type of storage was also observed for other species of the same family (Barbedo et al., 1998). Cold, dry environmental conditions are more favorable for storing orthodox seeds (Villela and Peres, 2004). The association between low temperature and impermeable packaging reduces cell metabolism and this affects seed longevity (Figliolia et al., 1993; Ferreira and Borgehtti, 2004).

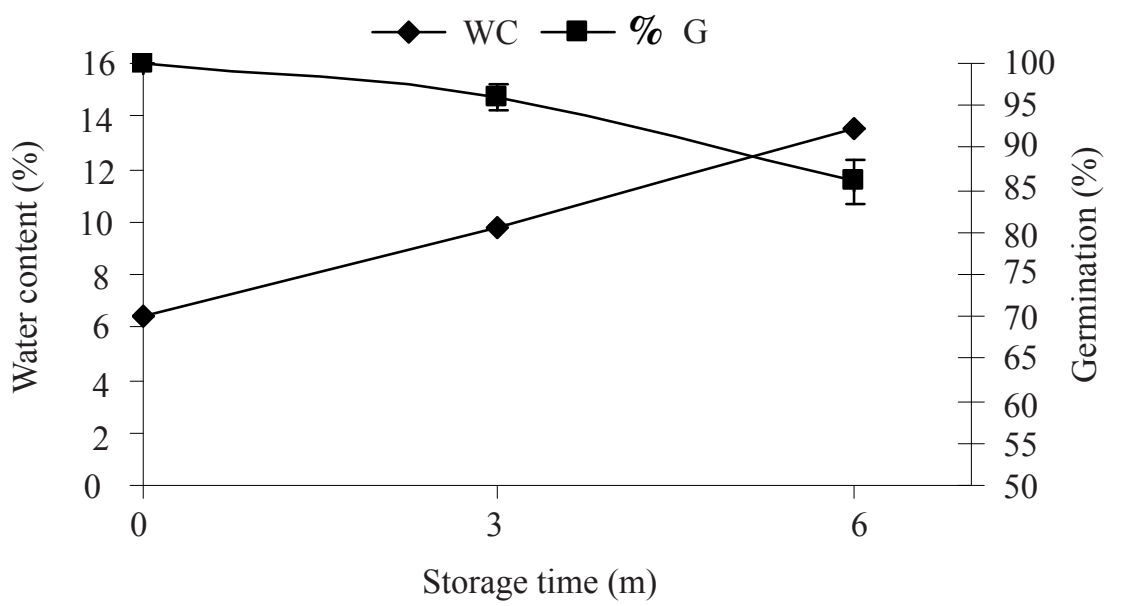

FIGURE 1. Water content (\%) and germination (\%) of Gliricidia sepium (Jacq.) Steud.(Leguminosae-Papilionoideae) seeds during storage (m). Vertical bars represent the mean standard errors.

The germination of stored gliricidia seeds decreased compared to freshly harvested seeds, as observed from the percentage of seeds that had germinated up to $96 \mathrm{~h}$ after the start of imbibition (Figure 2). Concomitant with this result, TSS content was significantly reduced in the cotyledons (Figure 3A) and this reduction was significant for six months storage where the lowest mean values were observed.

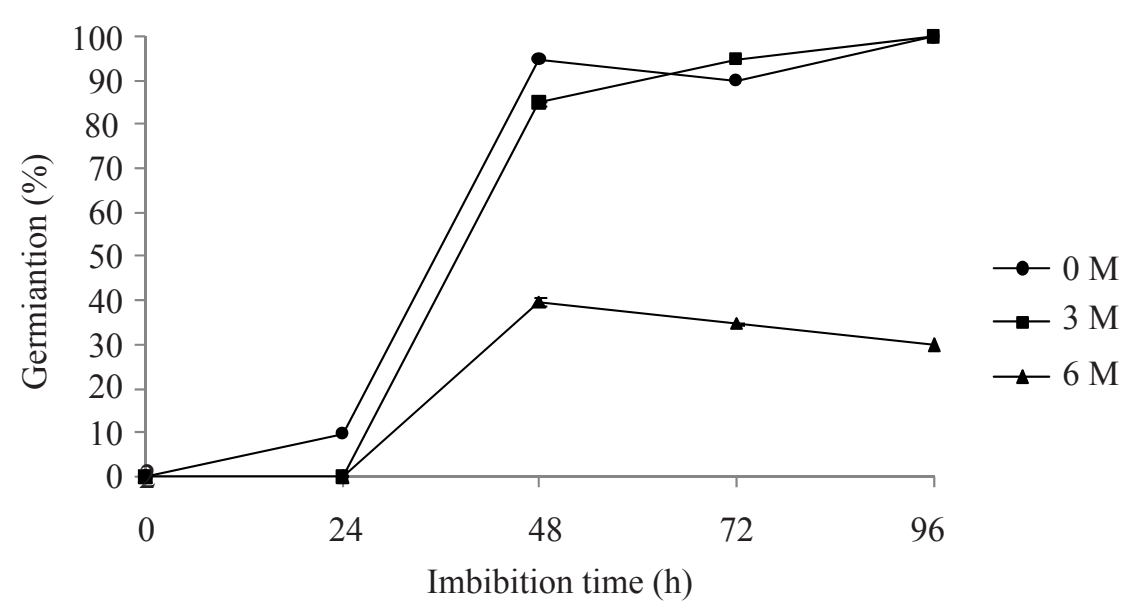

FIGURE 2. Germination (\%) of freshly harvested (0M) Gliricidia sepium (Jacq.) Steud. (Leguminosae Papilionoideae) seeds and after $3(3 \mathrm{M})$ and 6 months $(6 \mathrm{M})$ of storage. Vertical bars represent mean standard errors. 
$\mathbf{A}$

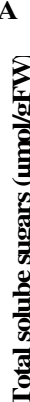

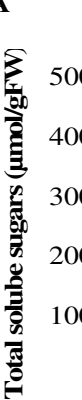

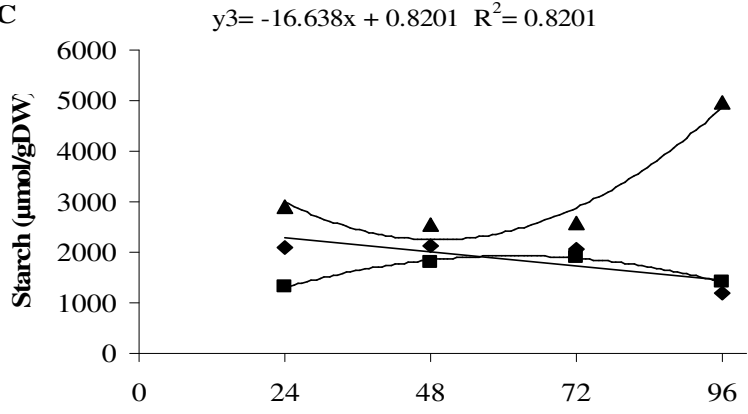

$y 1=-11.573 x+2553.2 R^{2}=0.6239$

$y 2=-0.4401 x^{2}+54.329 x+254.71 R^{2}=0.9929$

$\mathbf{E}$

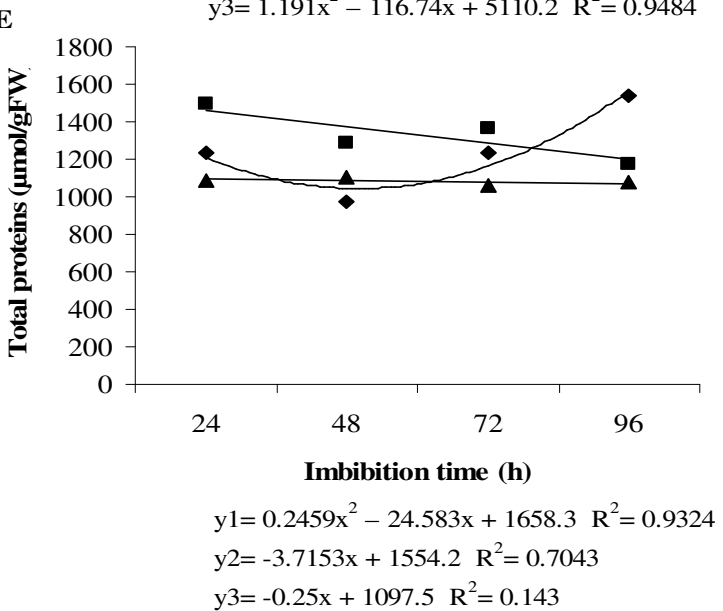

B
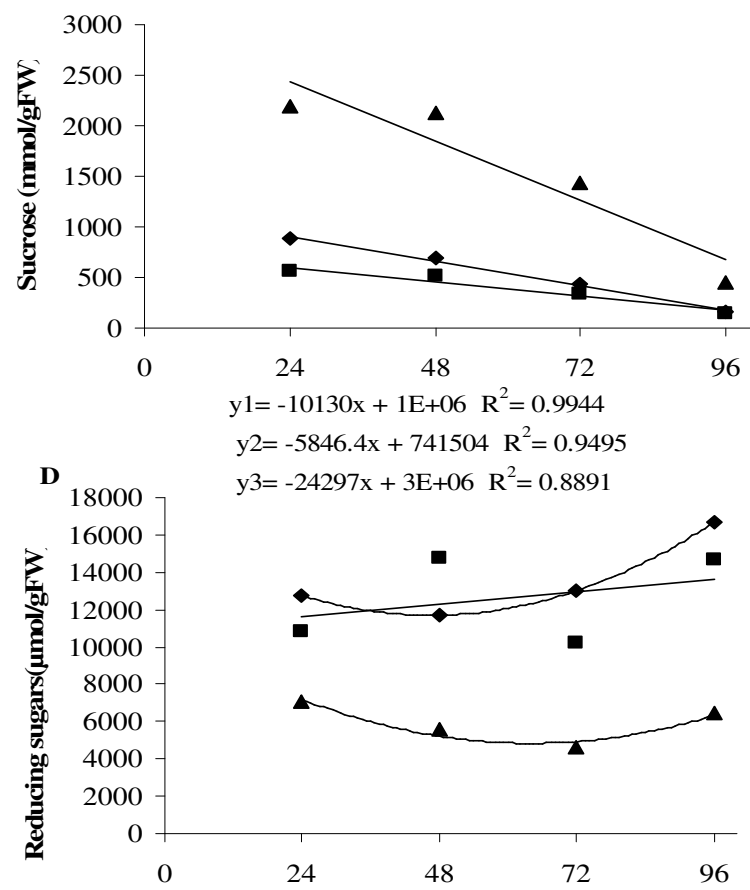

$\mathrm{y} 1=2.0434 \mathrm{x}^{2}-190.58 \mathrm{x}+16143 \mathrm{R}^{2}=0.9998$ $\mathrm{y} 2=28.375 \mathrm{x}+10928 \mathrm{R}^{2}=0.1345$

F

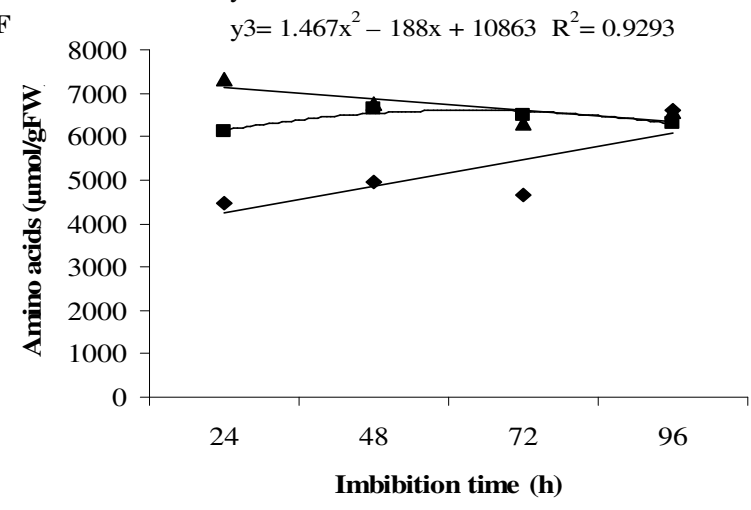

$y 1=25.666 x+3638.3 R^{2}=0.6547$ $y 2=-0.2986 x^{2}+37.851 x+5409.6 R^{2}=0.846$ $y 3=-11.078 x+7401.6 R^{2}=0.6484$

FIGURE 3. Cotyledon contents ( $\mu \mathrm{mol} / \mathrm{g} . \mathrm{DW}$ or $\mu \mathrm{mol} / \mathrm{g} . \mathrm{FW})$ of total soluble sugars (A), sucrose (B), starch (C), reducing sugars (D), total proteins (E) and amino acids (F) during imbibition of freshly harvested Gliricidia sepium (Jacq.) Steud. (Leguminosae - Papilionoideae) seeds and after 3 and 6 months of storage (m).

It has been reported that TSS is apparently used in cell respiration or released to the atmosphere during the initial imbibition phases, as observed in embryos of the legume, Senna macranthera (Borges et al., 2002). This supports our observations which showed that the TSS content decreased in cotyledons of imbibing gliricidia seeds (Figure 3A). Apparently, in Dalbergia miscolobium seedlings, the mobilization of these reserves occurs following radicle 
protrusion, and an increase in TSS levels in the roots, as well as in above-ground parts, was clearly observed during initial seedling development (Sassaki and Felippe, 1992).

The SUC and ST contents showed a slight decrease after three months storage but increased significantly after six months, as can be seen in those seeds imbibed for 24 h. Despite this period, SUC contents decreased during the imbibition of freshly harvested seeds, as well as for stored seeds, which is evidence of their mobilization by the embryonic axis (Figure 3B). However, this does not seem to be the case for seeds stored for six months, which showed a reduction in germination during the same periods (Figure 2) and, therefore, SUC may have been distributed via other metabolic pathways.

Part of the RS produced during degradation of the reserve carbohydrates is used in storage tissue cell respiration, which is the main source of energy during the initial stages of seed germination. Another part of RS is employed for the production of SUC that will be carried to the embryonic axis or S synthesis, when there is excess RS in storage tissues (Bewley and Black, 1994; Nelson and Coxswain, 2000). Synthesized ST is stored as an energy source for germination and subsequent seedling growth. According to Stone and Gifford (1999), starch accumulation in Pinus taeda seeds occurred in the megagametophyte tissue during radicle protrusion.

Starch content stayed at about the same level in cotyledons of freshly harvested and stored seeds until $72 \mathrm{~h}$ of imbibition (Figure 3C), after which contents decreased in freshly harvested seeds and in seeds stored for three months. On the other hand, a steep increase in ST content was observed in seeds that were stored for six months, in which an apparent re-synthesis of ST occurred after $96 \mathrm{~h}$ of imbibition (Figure 3C). The reduction which occurred in un-stored and seeds stored for a short period coincided with mobilization by the embryonic axis, possibly as a substrate for seedling development once seeds had initiated the germination process $48 \mathrm{~h}$ after imbibition (Figure 2).

As stated by Zeleny (1954), an increase in reducing sugars and posterior reduction in seeds, as observed with gliricidia seeds in the third month of storage (Figure 3D), seems to be associated with a loss of seed viability, due to the fact that these sugars are associated with reactions such as the Amadori and Maillard reactions, which induce seed deterioration by means of protein and amino acid degradation. As a result, TSS levels tend to diminish; however, for the species under study an increase in sucrose content occurred, possibly as a protection mechanism since the synthesis of this disaccharide seems to be involved in seed protection systems to combat deterioration processes (Kigel and Galili, 1995).

A significant increase in the RS contents in freshly harvested and three months stored seeds was observed after $96 \mathrm{~h}$ imbibition (Figure 3D), whereas the content was low in seeds stored for six months throughout the imbibition period.

A decrease in reducing sucrose during seed imbibition occurred in rubber tree seeds, as well as in gliricidia seeds (Figure 3D), which partially explains the processing and use of these sugars in seed metabolic processes. However, De Paula et al. (1998) suggested that RS participated in Amadori and Maillard reactions.

On the other hand, the increase in hydration levels of gliricidia seeds after the third month of storage (Figure 1) may have triggered the activation of invertases and $\alpha$-galactosidases. According to Wettlaufer and Leopold (1991), relatively high levels of seed hydration are necessary, resulting in activation of these same enzymes and a consequent promotion of increased RS levels that will directly participate in Amadori and Maillard reactions and cause a cellular deficiency of these compounds. Salisbury and Ross (1992) declared that serious disturbances can occur in cells due to a loss of RS. This can be triggered because some of these sugars are important intermediate compounds in photosynthetic metabolic pathways and cellular respiration. They also constitute basic compounds for the synthesis of many other carbohydrates, including starch and cellulose.

In general, the TP levels of stored gliricidia seeds showed few changes throughout the imbibitions period. The lowest levels of TP were verified in seeds stored for six months and those levels remained low during the period of imbibition (Figure 3E). The behaviour of seeds stored for three months also showed a significant reduction, reaching levels of TP similar to those of seeds stored for six months $96 \mathrm{~h}$ after imbibition. A different protein profile was observed for freshly harvested gliricidia seeds, whose levels had decreased in the first $48 \mathrm{~h}$ and later increased until reaching $96 \mathrm{~h}$ after imbibition (Figure 3E).

AA contents showed a significant increase in the 24 hour imbibed cotyledons of three and six months stored seeds. For further imbibition periods there was no significant difference in the AA content of stored seeds, which was higher than in recently harvested seeds until 96 hours. At this stage all seeds had similar cotyledon AA (Figure 3F).

The increase in AA in early germinating stored seeds 
compared with recently harvested seeds probably occurred due to activation of proteinases present in seeds, and their role in degrading reserve proteins and producing free amino acids. According to Smith and Berjak (1995), these enzymes can increase their activity with the seed aging process. Later, amino acid levels tend to diminish through their self-destruction, due to Amadori and Maillard reactions, that according to Wettlaufer and Leopold (1991), is characterized by non-enzymatic attack on amine groups by RS. This effect has been verified in rubber tree seeds (De Paula et al., 1998), and probably also in G. sepium seeds (Figure 3F).

Enzyme activity during imbibition and germination of the gliricidia seeds followed the same pattern for total amylase activity. The $\alpha$-amylase activity varied according to the duration of seed storage (Figure 4A, B). In general, total amylase activity of the dry seeds was similar over the entire period of seed storage (Figure 4B); however, $\alpha$-amylase activity increased in the third and sixth month of storage (Figure 4A). This initial increase can be attributed to the effects of the hydration of seed tissues (Figure 1) that would cause alterations in seed metabolism during storage.

A $\bullet 0 \mathrm{~m}(\mathrm{y} 1) \boldsymbol{\square} \mathrm{m}(\mathrm{y} 2) \boldsymbol{\Delta} 6 \mathrm{~m}(\mathrm{y} 3)$
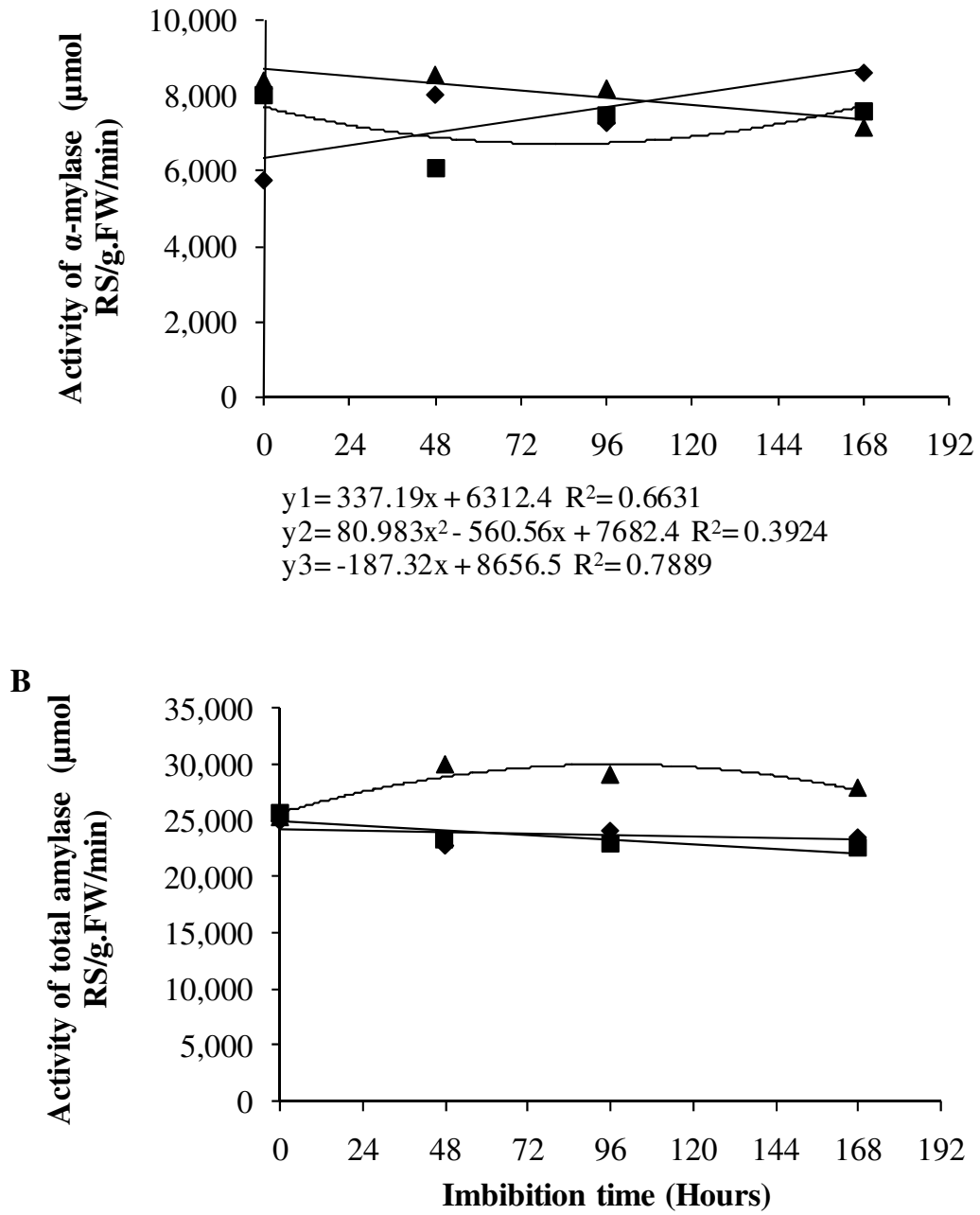

$$
\begin{aligned}
& y 1=-127.88 x+24230 R^{2}=0.1644 \\
& y 2=-419.91 x+24948 R^{2}=0.7355 \\
& y 3=-261.28 x^{2}+2114.3 x+25726 R^{2}=0.8185
\end{aligned}
$$

FIGURE 4. Activity of $\alpha$-amylase (A) and total amylases (B) in the cotyledons of stored Gliricidia sepium (Jacq.) Steud. (Leguminosae - Papilionoideae) seeds during germination. 
High water content is one of the principal causes of the loss of germination vigor during storage (Villela and Perez, 2004). High seed humidity causes an increase in the seed's respiration rate, mobilizes energy reserves and accelerates seed deterioration. The energy liberated in these processes will be taken from the stored reserves required to initiate germination (Marcos Filho, 2005).

An increase in the water content of rubber tree seeds likewise initiated seed deterioration (De Paula et al., 1998). The principal alterations documented for seed deterioration include the exhaustion of food reserves, alteration in the chemical composition of seed components (such as the oxidation of lipidic components), the partial degradation of proteins, the alteration of cell membranes (which results in the reduction of their integrity and organization, with a consequent increase in their permeability), as well as enzymatic alterations and modifications of the nucleotides (Ferreira and Borghetti, 2004).

During the imbibition of recently collected gliricidia seeds, the levels of $\alpha$-amylase increased, showing a peak of activity on the seventh day (Figure 4A). Total amylase activity was little altered during imbibition, remaining at high levels; and this enzyme activity is correlated with the high germination levels observed in these fresh seeds (Figure 5). The differences in germination rates after six months can explain the patterns of enzyme activity observed for gliricidia seeds. Note that seeds required a longer imbibition period after six months of storage in order to germinate (Figure 5).

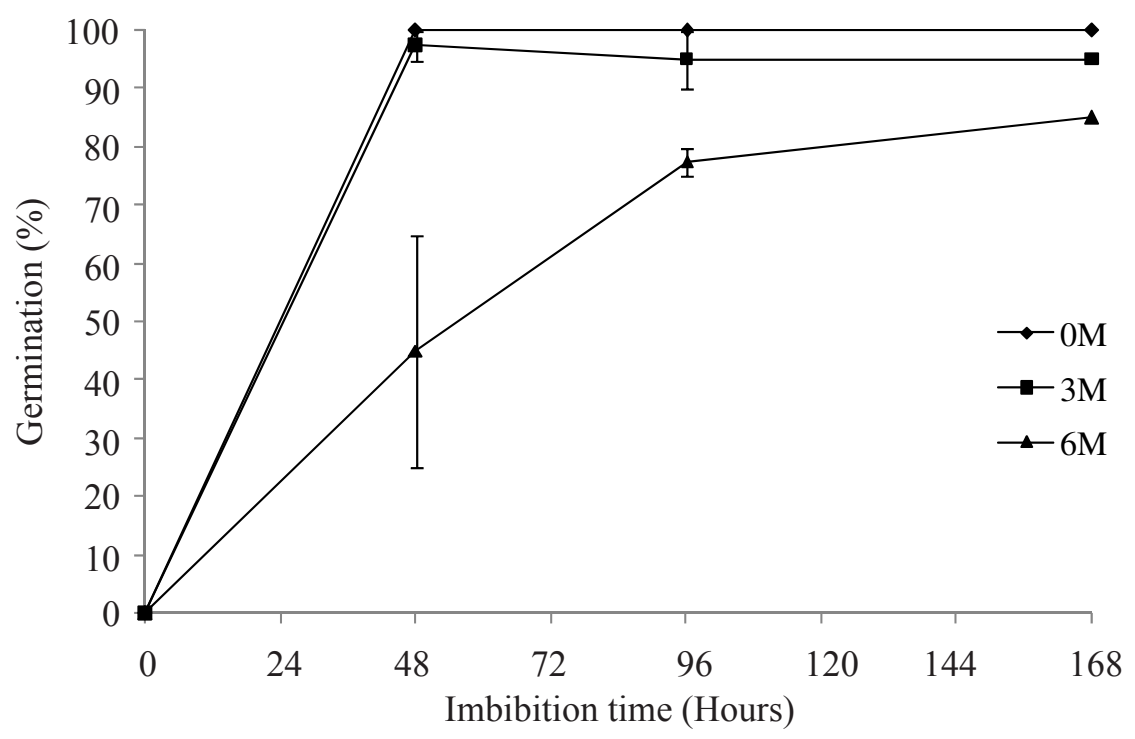

FIGURE 5. Germination (\%) of stored Gliricidia sepium (Jacq.) Steud. (Leguminosae - Papilionoideae) seeds during imbibition. Average of four repetitions \pm ASE. Vertical bars represent mean standard errors.

Storage for six months altered $\alpha$-amylase activity levels and these remained at a constant level until the 96 hours of imbibition (Figure 4A). Total amylase levels during seed imbibition were higher in seeds stored for six months than in those observed in the other storage treatments (Figure 4B).

The observed tendency of increasing levels of overall amylase activity over time during imbibition may represent a mechanism for compensating the loss of vigor caused by longer periods of storage.

As enzymatic activity is required for germination, any alteration of seed metabolism caused by an increase in its water content will adversely affect seed survival - as can be observed in the reduced vigor of gliricidia seeds over time (Figure 4).

Alpha-amylase demonstrates high activity levels at the start of germination, but its enzymatic activity decreases with time, which can be attributed to the reduction in starch levels as germination proceeds (Bewley and Black, 1994). Aragão et al. (2003) observed this same pattern of amylase activity in sweet corn seeds. Many studies have correlated a decrease in amylase activity with a loss of seed viability and decreasing amylase activity has been reported in cereal grains as a consequence of aging (Muniz et al., 2007).

On most occasions, a lack of knowledge of the ideal storage conditions makes the maintenance of physiological 
seed quality for long periods more difficult and, therefore, the aging of seeds occurs naturally. The present results showed that the ambient storage condition did not result in good conservation of gliricidia seeds.

It cannot be concluded from the present study that similar processes occur or what the factors responsible for maintaining the viability of G. sepium seeds are while stored under the natural conditions of soil seed banks in the semi-arid region. Therefore, further studies are needed in order to better characterize the viability, longevity and storage tolerance of G. sepium seeds and to better understand their conservation and capacity to successfully establish seedlings and promote plant growth under adverse conditions.

\section{CONCLUSIONS}

Since the main objective of seed storage is to maintain seed quality, it can be concluded that the storage conditions employed in this study were not ideal as they resulted in physiological alterations that decreased the quality of gliricidia seed germination.

The alteration in the macromolecular composition of seed cotyledons is apparently responsible for the changes associated with seed deterioration processes throughout the storage period.

\section{ACKNOWLEDGMENTS}

We would like to thank the following organizations for their valuable and generous funding and technical support: Conselho Nacional de Desenvolvimento Científico e Tecnológico (CNPq) Fundação de Amparo a Pesquisa do Estado da Bahia (FAPESB), Embrapa Semiárido.

And José Juracy Pereira for providing access to the biological material on his property.

\section{REFERENCES}

ALIZAGA, R.L.; MELLO, V.D.C.; SANTOS, D.S.B.; IRIGON, D.L. Avaliações de testes de vigor em sementes de feijão e suas relações com a emergência em campo. Revista Brasileira de Sementes, v.12, n.2, p. 44-58, 1990. http://www.scielo.br/pdf/rbs/v26n2/24498.pdf

ALLEN, S.E.; GRIMSHAW, H.M.; PARKINSON, J.A.; QUARMBY, C. Chemical analysis of ecological materiais. Oxford. Blackwell Scientific, 1977. 565p.
ARAGÃO, C.A.; DANTAS, B.F.; ALVES, E.; CATANEO, A.C.; CAVARIANI, C.; NAKAGAWA, J. Atividade amilolítica e qualidade fisiológica de sementes armazenadas de milho super doce tratadas com ácido giberélico. Revista Brasileira de Sementes, v.25, n.1, p.43-48, 2003. http://www.scielo.br/pdf/rbs/ v25n1/19629.pdf

ARAÚJO, J.M.A. Química de alimentos: teoria e prática. Viçosa: UFV, Imprensa Universitária, 1995, 335p.

BARBEDO, C.J.; KOHAMA, S.; MALUF, A.M.; BILIA, D.A.C. Germinação e armazenamento de diásporos de cerejeira (Eugenia involucrata DC.- Myrtaceae) em função do teor de água. Revista Brasileira de Sementes, v.20, p.184-188, 1998.

BASKIN, C.C.; BASKIN, J.M. Seeds, ecology, biogeography, and evolution of dormancy and germination. New York. Academic Press, 1998.

BEWLEY, J.D.; BLACK, M. Seeds: physiology of development and germination. New York: Plenum Press, 1985. 367p.

BEWLEY, J.D.; BLACK, M. Seeds: physiology of development and germination. $2^{\text {th }}$ ed. New York. Plenum Press, 1994.

BORGES, E.E.L.; BORGES, R.C.G. de.; SOARES, C.P.B.; PEREZ, S.C.J.G.A. de. Crescimento e mobilização de carboidrato em embrião de sementes de fedegoso (Senna macranthera Irwis et Barneby) durante a germinação. Revista CERNE, v.8, n.1, p.69-76, 2002.

BRASIL. Ministério da Agricultura e da Reforma Agrária. Regras para análise de sementes. Secretaria Nacional de Defesa Agropecuária. Departamento Nacional de Produção Vegetal. Coordenação de Laboratório Vegetal. Brasília, DF, 1992, 365p.

CISNEIROS, R.A.; MATOS, V.P.; LEMOS, M.A.; REIS, O.V.; QUEIROZ, R.M. Qualidade fisiológica de sementes de araçazeiro durante o armazenamento. Revista Brasileira de Engenharia Agronômica e Ambiental, Campina grande, v.7, n.3, p.513-518, 2003.

BUCKERIDGE, M.S.; SANTOS, H.P.; TINÉ, M.A.S.; ADAIR, M.P.M. Mobilização de reservas. In:FERREIRA, A.G.; BORGHETTI, F. (Org.). Germinação do básico ao aplicado. Porto Alegre. ARTMED, p.163-185, 2004.

DE PAULA, N.F.; BORGES, E.E.L.; BORGES, R.C.G., DE PAULA, R.C. Avaliações bioquímicas e fisiológicas em sementes de seringueira (Hevea brasiliensis Muell. Arg.). Revista Brasileira de Sementes, v. 20, n.2, p. 1-10, 1998. http://www.abrates.org.br/revista/artigos/1998/ 
v20n2/artigo01.pdf

DRUMOND, M.A.; CARVALHO FILHO, O.M. de. Introdução e avaliação de Gliricidia sepium na região semi-árida do Nordeste Brasileiro. Disponível: http://www.cpatsa.embrapa.br:8080/catalogo/livrorg/ gliricidia.pdf. Acesso em: 3 set. 2007.

FERREIRA, A.; BORGHETTI, F. (Org.). GerminaçãoDo básico ao aplicado. Porto Alegre. Artmed, 2004. $323 p$.

FERREIRA, D.F. 2000. Análises Estatísticas por meio do Sisvar para Windows versão 4.0. In: REUNIÃO ANUAL DA REGIÃO BRASILEIRA DA SOCIEDADE INTERNACIONAL DE BIOMETRIA, 45., 2000, São Carlos, SP. Programas e Resumos... São Carlos: UFSCAR, 2000. p.235.

FIGLIOLIA, M.B.; OLIVEIRA, E.C.; PIÑARODRIGUES, F.C.M. Análise de sementes. In: AGUIAR, I.B.; PIÑA-RODRIGUES, F.C.M.; FIGLIOLIA, M.B. (Coord.). Sementes florestais tropicais. Brasília: ABRATES, p.137-174, 1993.

FREITAS, G.B.; SILVA, R.F.; ARAÚJO, E.F. Influência da condição de armazenamento na qualidade de sementes de milho. Revista Brasileira de Armazenamento, Viçosa, v.17, n.1, p.21-26, 1992.

GUGELMINETTI, L.; YAMAGUCHI, J.; PERATA, P.; ALPI, A. Amilolytic activities in cereal seeds under aerobic and anaerobic conditions. Plant Physiology, v.109, n.1, p.1069-1076, 1995.

HOEKSTRA, F.A.; GOLOVINA, E.A.; NIJSSE, J. What do we know about desiccation tolerance mechanism?. In: NICOLAS, G.; BRADFORD, K.J.; CÔME, D.; PRITCHARD, H.D. (Ed.). The biology of seeds: resent research advances. Cambridge. CAB International, p.259-270, 2003.

KIGEL, J.; GALILI, G. Seed development and germination. New York. Marcel Dekker, 1995, 853p.

MALUF, A.M.; PISCIOTTANO-EREIO, W.A. Secagem e armazenamento de sementes de cambuci. Pesquisa Agropecuária Brasileira, v.40, n.7, p.707-714, 2005. http://www.scielo.br/pdf/pab/v40n7/a12v40n7.pdf

MARCOS FILHO, J. Fisiologia de sementes de plantas cultivadas. Piracicaba: FEALQ, 2005, 495p.

MILLER, G.L. Use of dinitrosalicilic acid reagent for determination of reducing sugar. Analytical Chemistry, v.31, p.426-428, 1959.
MORRIS, D.L. Quantitative determination of carbohydrates with Drywood's anthrone reagent. Science, v.107, p.254-255, 1948.

MUNIZ, F.R.; CARDOSO, M.G.; PINHO, E.V.R.V.; VILELA, M. Qualidade fisiológica de sementes de milho, feijão, soja e alface na presença de extrato de tiririca. Revista Brasileira de Sementes, v.29, n.2, p.195-204, 2007. http://www.scielo.br/pdf/rbs/v29n2/v29n2a26.pdf

NELSON, D.L.; COX, M.M. Lehninger principles of biochemistry. 3.ed. New York. Worth Publishers, 2000.

PASSOS, L.P. Métodos analíticos e laboratoriais em fisiologia vegetal. Coronel Pacheco. Embrapa-CNPGL, 1996, 223p.

ROSEN, H. A modified ninhydrin calorimetric analysis for amino acids. Archives of Biochemistry and Biophysics, v.67, p.10-15, 1957.

SAlisBurY, F. B.; ROSS, C. W. Plant Physiology. California, Wadsworth Publishing Company, 1992, $682 \mathrm{p}$.

SAMPAIO, E.; RODAL, M.J. Fitofisionomias da caatinga. GT Estratégias para o uso sustentável da biodiversidade da caatinga. Seminário sobre Avaliação e Identificação de Ações Prioritáriias para a Conservação, Utilização Sustentável e Repartição de Benefícios da Biodiversidade do Bioma Caatinga. 2000. Petrolina: CPATSA/ EMBRAPA, 14p.

SASSAKI, R.M.; FELIPPE, G.M. Remoção dos cotilédones e desenvolvimento inicial de Dalbergia miscolobium. Revista Brasileira de Botânica, v.5, p.5-6, 1992.

SEIFFERT, M. Alguns aspectos fisiológicos e bioquímicos da germinação de sementes e anatomia foliar deProtium widgreniiEngler. 2003. 81f.Dissertação (Mestrado em Fisiologia Vegetal) - Universidade Federal de Lavras, Lavras.

SMITH, M.T.; BERJAK, P. Deteriorative changes associated with the loss of viability of storage desiccation-tolerant and desiccation-sensitive seeds. In: KIMOJEL, Y. \& GOLILI, G. (Eds.) Seed development and germination. New York: Marcel Dekker Inc., 1995, p.701-746.

STONE, S.L.; GIFFORD, D.J. Structural and biochemical changes in Loblolly pine (Pinus taeda) seeds during germination and early seedling growth. 11. Storage triacylglicerols and carbohydrates. International Journal Plant Science, v.160, n.4, p.663-671, 1999. 
TEIXEIRA, A.H.C. Informações Agrometeorológicas do Pólo Petrolina-PE/Juazeiro - BA. Documentos. Embrapa Semi-Árido, Petrolina-PE, 2001.

VILLELA, F.A.; PERES, W.B. Coleta, beneficiamento e armazenamento. In: Ferreira, A.G.; Borghetti, F. (Ed.). Germinação: do básico ao aplicado. Porto Alegre. Artmed, p.265-281, 2004.

WARD, F.H.; POWELL, A.A. Evidence for repair processes in onion seeds during storage at high seed moisture contents. Journal of Experimental Botany, v.34, n.140, p.277-282, 1983.
WETTLAUFER, S.H.; LEOPOLD, A.C. Relevance of Amadori and Maillard products to seed deterioration. Plant Physiology, v.97, n.1, p.165-169, 1991.

YEMM, E.W.; WILLIS, A.J. The estimation of carbohydrates in plants extracts by anthrone. Biochemical Journal, v.57, p.508-514, 1954.

ZELENY, L. Chemical, physical, and nutritive changes during storage. In: Anderson, J.A.; Alcock, A.W. (Ed.). Storage of cereal grains and their products. Minnesota. American Association of Cereal Chemists, p.46-76, 1954. 